long-term oral 1,25-dihydroxyvitamin D in childhood renal osteodystrophy. Contr Nephrol 18:55

12. Delmez JA, Slatopolsky E, Martin KJ, Gearing BN, Harter HR 1982 The effects of continuous ambulatory peritoneal dialysis on mineral metabolism. Kidney Int 21:862

13. Digenis G, Khanna R, Pierratos A, Mena HE, Rabinovich S, Petit J, Oreopoulos DG 1983 Renal osteodystrophy in patients maintained on CAPD for more than three years. Perit Dial Bull 2:81

14. Fine RN 1982 Peritoneal dialysis update. J Pediatr 100:1

15. Gertner JM, Tamborlane WV, Horst RL, Sherwin RS, Felig P, Genel M 1980 Mineral metabolism in diabetes mellitus: Changes accompanying treatment with a portable subcutaneous insulin infusion system. J Clin Endocrinol Metab 50:862

16. Gokal R, Ellis A, Ramos JM, Dewar J, Sweeting V, Ward MK, Kerr DNS 1981 Improvement in secondary hyperparathyroidism in patients on continuous ambulatory peritoneal dialysis (CAPD). In: Gahl GM, Kessel M, Nolph DK (eds) Advances in Peritoneal Dialysis. Excerpta Medica, Amsterdam, pp 461-466

17. Guillot M, Clermont MJ, Gagnadoux MF, Broyer M 1981 Nineteen months experience with continuous ambulatory peritoneal dialysis (CAPD) in children: main clinical and biological results. In: Gahl GM, Kessel M, Nolph $\mathrm{KD}$ (eds) Advances in Peritoneal Dialysis. Excerpta Medica, Amsterdam pp 203-207

18. Guillot M, Lavocat C, Garabedian M, Sachs C, Balsan S, Gagnadoux MF, Broyer M 1981 Evaluation of 25(OH)D loss in dialysate of children on continuous ambulatory peritoneal dialysis. Proc Eur Dial Transplant Assoc $18: 290$

19. Harrington JT 1982 Chronic ambulatory peritoneal dialysis. N Engl J Med 306:670

20. Hewitt IK, Stefanidis C, Reilly BJ, Kooh SW, Balfe JW 1983 Renal osteodys trophy in children undergoing continuous ambulatory peritoneal dialysis. $\mathrm{J}$ Pediatr 103:729

21. Horst RL, Littledike ET, Riley JL, Napoli JL 1981 Quantitation of vitamin D and its metabolites and their plasma concentrations in five species of animals.
Ann Biochem 116:189

22. Hruska KA, Kopelman R, Rutherford WE, Klahr S, Slatopolsky E 1975 Metabolism of immunoreactive parathyroid hormone in the dog. The role of the kidney and the effects of chronic renal disease. J Clin Invest 56:39

23. Kurtz SB, McCarthy JT, Kuman R 1981 Hypercalcemia in continuous ambulatory peritoneal dialysis (CAPD) patients: observations on parameters of calcium metabolism. In: Gahl GM, Kessel M, Nolph KD (eds) Advances in Peritoneal Dialysis. Excerpta Medica Amsterdam, pp 467-472

24. Oreopoulos DG, Robson M, Izatt S, Clayton S, DeVeber GA 1979 A simple and safe technique for continuous ambulatory peritoneal dialysis (CAPD). Am Soc Artif Intern Organs 24:484

25. Parker A, Nolph KD 1981 Magnesium and calcium mass transfer during continuous ambulatory peritoneal dialysis. Am Soc Artif Intern Organs 26:184

26. Salusky IB, Lucullo L, Nelson P, Fine RN 1982 Continuous ambulatory peritoneal dialysis in children. Ped Clin N Am 29:1005

27. Salusky IB, Kopple JD, Fine RN 1983 Continuous ambulatory peritoneal dialysis in pediatric patients-20 months experience. Kidney Int 24: S-101 (suppl 15)

28. Salusky IB, Nelson P, Fine RN 1984 Nutritional management of pediatric patients on dialysis. In: Nissensson A, Fine RN, Gentile D (eds) Clinical Dialysis. Appleton-Century-Crofts, New York (in press)

29. Tielemans C, Aubry C, Dratwa M 1981 The effects of continuous ambulatory peritoneal dialysis (CAPD) on renal osteodystrophy. In: Gahl GM, Kessel M, Nolph KD 1981 Advances in Peritoneal Dialysis. Excerpta Medica, Amsterdam, pp 455-460

30. This research was supported in part by United States Public Health Service Grant AM 14750, Veterans Administration Research Funds, and the Peter Boxenbaum Foundation.

31. The authors appreciate the technical assistance of J. Lee, R. Adachi, H. Dennin, S. Soghomonian, and A. Landsberg.

32. Requests for reprints should be addressed to Luc Paunier, M.D., Clinique de Pédiatrie, Hôpital Cantonal Universitaire, CH-1211 Geneva 4, Switzerland. 33. Received for publication February 3, 1984.

\title{
Cysteine Supplementation of Total Parenteral Nutrition: the Effect in Beagle Pups
}

\author{
MICHAEL H. MALLOY ${ }^{(28)}$ AND DAVID K. RASSIN \\ Department of Pediatrics, The University of Texas Medical Branch, Galveston, Texas, USA
}

\section{Summary}

Total parenteral nutrition solutions supplemented with cysteine-HCl (S-TPN, $0.8 \mathrm{mmol} / \mathrm{kg} / \mathrm{day})$ were infused into beagle pups from day 10 of life to day $20(n=6)$. Another group of pups received unsupplemented TPN solutions (US-TPN) $(n=$ 6). Fluid, protein, and energy intake from nonprotein sources were similar in both groups. Data from these two groups were compared and similar measurements in normally suckled pups were also compared with the two TPN groups $(n=6)$.

There were significant differences in the rate of weight gain between the pups that received TPN and the pups that were suckled $(P<0.01)$. Weight gain, hepatic DNA and protein concentrations, and cerebral DNA and protein concentrations in the pups that received TPN supplemented with cysteine were not different from similar measurements in pups that received unsupplemented TPN. Plasma total cyst(e)ine (Cyst(e)ine refers to the mixture in any proportion of the sulfhydryl (cysteine) and the disulfide (cystine) forms of this compound) concentrations in the cysteine-supplemented pups $(7.9 \pm 1.2 \mu \mathrm{mol} / \mathrm{DL}, \times \pm \mathrm{SD})$ were significantly greater than in the unsupplemented pups $(4.9 \pm 1.8$ $\mu \mathrm{mol} / \mathrm{DL})$. Hepatic glutathione concentrations in the supplemented pups $(583 \pm 85 \mu \mathrm{mol} / 100 \mathrm{~g}$ liver $)$ were also significantly greater than in the unsupplemented pups $(392 \pm 113 \mu \mathrm{mol} / 100$ $\mathrm{g}$ liver). These data suggest that the supplementation of TPN solutions with cysteine, even in an animal enzymatically capable of cysteine synthesis, has significant effects on glutathione synthesis.

\section{Abbreviations}

TPN, total parenteral nutrition;

US-TPN, unsupplemented total parenteral nutrition;

S-TPN, cysteine-supplemented total parenteral nutrition

Cysteine is a sulfhydryl-containing compound that in adult man may be synthesized from methionine via the transsulfuration pathway (19). In the newborn, cysteine may be an essential amino acid (6). This hypothesis is based upon the observation that cystathionase activity, the rate-limiting enzyme for the synthesis of cysteine from methionine, is not present in the second 
trimester human fetus (6). Although it has been documented that cystathionase activity increases rapidly after birth even in premature infants (22), concern still exists that an exogenous source of cysteine may be required in the first weeks of life. Cysteine is also necessary for the synthesis of glutathione (14), and it is a precursor for the synthesis of taurine (8) (Fig. 1).

Clinical studies that have attempted to document a requirement for cysteine during enteral nutrition suggest that, in the absence of an exogenous source of cysteine, nitrogen retention and weight gain in premature infants are impaired (17). Studies of cysteine supplemented during TPN have failed to document an enhancement of nitrogen retention or growth in infants receiving cysteine $(13,23)$. The supplementation of TPN solutions with cysteine does, however, appear to have a positive effect on sulfur retention $(13,24)$.

Amino acid preparations used in TPN solutions contain only trace amounts of cysteine. When cysteine is added to TPN solutions, it is added in the form of cysteine- $\mathrm{HCl}$ and administered over a $24-\mathrm{h}$ period. The provision of cysteine in this manner obviates the problem of the oxidation of cysteine to cystine and precipitation of less soluble cystine. Thus, unlike common enteral nutritional preparations that contain an abundance of cysteine, the provision of nutrition parenterally requires that a decision be made whether or not to supplement with cysteine. Based on clinical studies, the indications for supplementing TPN solutions with cysteine are not clear $(13,23)$.

In order to examine the effects of supplementing TPN solutions with cysteine on the biochemistry of individual organs, a study difficult to conduct in human infants, we have used an animal model, the beagle pup.

\section{MATERIALS AND METHODS}

We obtained pregnant beagles from a commercial breeder (White Eagle Laboratories, Doylestown, PA) at 4 weeks of gestation and cared for them in the University of Texas Medical Branch Animal Care Facility until delivery. Six litters of pups were used. From birth until 10 days of life, all pups were allowed to nurse from their mothers. On day 10 , the pups were randomly assigned to remain with their mothers as suckled controls, to receive TPN, or to receive TPN supplemented with cysteine. Litter sizes ranged from four to eight pups. The number of pups remaining with the mother as suckled controls was two to three.

Those pups selected to receive US-TPN or S-TPN had central venous catheters surgically placed and received their randomly assigned TPN regimen until day 20 of life. The experimental pups were free to move in a $2 \times 2 \times 2$ foot metal cage. The pups were connected to an infusion swivel by a coiled spring cable that was attached to the pups' back by a stainless steel metal button that was sutured into place. The swivels were connected to syringes on an infusion pump that administered the TPN solutions at continuous rates of from $3-6 \mathrm{ml} / \mathrm{h}$ over a $24-\mathrm{h}$ period. The pups were weighed daily.

The TPN solution was formulated to provide an amino acid intake equivalent to $8 \mathrm{~g} / \mathrm{kg} /$ day of protein, a total energy intake of $170 \mathrm{cal} / \mathrm{kg} /$ day and $2 \mathrm{~g} / \mathrm{kg} /$ day of fat. These quantities approximate the recommendations from the National Academy of Sciences (15) for growing pups, although the total energy intake that is recommended is somewhat higher than we provided $(200$

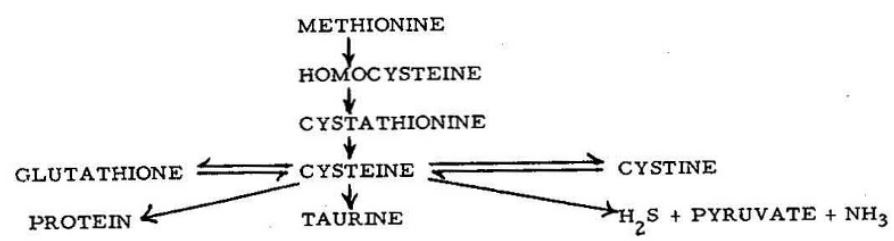

Fig. 1. Major components of transsulfuration pathway and cysteine metabolism.
$240 \mathrm{cal} / \mathrm{kg} /$ day). The composition of the TPN solution is listed in Table 1 . The actual intake received by each experimental pup was recorded daily, and the mean fluid, protein, fat, and energy intake from nonprotein sources for the US-TPN and S-TPN groups is listed in Table 2 . Cysteine $(0.8 \mathrm{mmol} / \mathrm{kg} /$ day $)$ was added to the supplemented group's TPN solution in the form of cysteine- $\mathrm{HCl}$ (Abbott Laboratories, North Chicago, IL). The cysteine was added to $30-35 \mathrm{ml}$ of TPN solution in a syringe and infused over a period of 6-8 h. The quantity of cysteine infused $(0.8 \mathrm{mmol} / \mathrm{kg} /$ day $)$ approximates the quantity of cysteine present in $8 \mathrm{~g}$ of bitch milk protein.

On day 20 of life, the control and experimental animals were anesthetized with Pentothal and then decapitated. Blood was drained from the carcass into heparinized tubes and the plasma and red blood cells were separated by centrifugation at $1000 \times$ $g$. There was no visual evidence of hemolysis in the plasma. After separation of the plasma from the cells, the plasma protein was precipitated with $3 \%$ sulfosalicylic acid and the protein pellet separated from the supernatant solution by centrifugation at $17,000 \times g$ for $20 \mathrm{~min}$. The plasma protein pellet and supernatant solution were then frozen at $-20^{\circ} \mathrm{C}$ until time of analysis, and the red blood cells were retained at $4^{\circ} \mathrm{C}$. The brain was dissected from the skull and separated into right and left cerebral hemispheres, cerebellum, and brainstem. Each portion was weighed individually and frozen at $-20^{\circ} \mathrm{C}$. Within $3-4$ weeks, one cerebral hemisphere was homogenized in a glass-to-glass homogenizer in a $0.15 \mathrm{M}$ potassium phosphate buffer, $\mathrm{pH} 7.4$. An aliquot of this

Table 1. Parenteral nutrition solution components

\begin{tabular}{lc}
\hline \multicolumn{1}{c}{ Component } & Concentration \\
\hline Amino acids* & $53 \mathrm{~g} / \mathrm{liter}$ \\
Glucose & $200 \mathrm{~g} / \mathrm{liter}$ \\
Sodium chloride & $33 \mathrm{meq} / \mathrm{liter}$ \\
Potassium phosphate & $33 \mathrm{meq} / \mathrm{liter}$ \\
Calcium gluconate & $10 \mathrm{meq} / \mathrm{liter}$ \\
Magnesium sulfate & $2.6 \mathrm{meq} / \mathrm{liter}$ \\
Copper & $200 \mu \mathrm{g} / \mathrm{liter}$ \\
Zinc & $667 \mu \mathrm{g} / \mathrm{liter}$ \\
Multivitamin concentrate $\dagger$ & $7 \mathrm{ml} / \mathrm{liter}$ \\
\hline
\end{tabular}

* Amino acids provided by Aminosyn (Abbott Laboratories, North Chicago, IL), $\mathrm{g} / 100 \mathrm{~g}$ amino acids; isoleucine $=7.3$; leucine $=9.5$; lysine $=7.3$; methionine $=4.0 ;$ phenylalanine $=4.4$; threonine $=5.3$; tryptophan $=1.7 ;$ valine $=8.0 ;$ tyrosine $=0.6 ;$ alanine $=12.9 ;$ arginine $=10.0 ;$ histidine $=3.0 ;$ proline $=8.8$; serine $=4.3$; glycine $=12.9$.

$\dagger$ Multivitamin concentrate (USV Pharmaceutical, NY), each 5-cc concentrate vial contains: ascorbic acid $=500 \mathrm{mg}$; vitamin $A=10,000$ USP units; vitamin $D=1,000$ USP units; thiamine $=50 \mathrm{mg}$; riboflavin $=10 \mathrm{mg}$; niacinamide $=100 \mathrm{mg}$; pyridoxine $-\mathrm{HCL}=15 \mathrm{mg}$; despanthenol $=25 \mathrm{mg}$; $d$ l- $\alpha$ tocopheryl acetate $=5 \mathrm{IU}$.

Table 2. Nutritional intake

\begin{tabular}{|c|c|c|c|}
\hline . & Control* & TPN & $\begin{array}{l}\text { TPN + } \\
\text { cysteine }\end{array}$ \\
\hline Fluid (ml/kg/day) & Suckled & $165 \pm 13$ & $176 \pm 15$ \\
\hline Protein $\dagger$ (g/kg/day) & Suckled & $7.7 \pm 0.6$ & $8.3 \pm 0.7$ \\
\hline Fatł (g/kg/day) & Suckled & 2.0 & 2.0 \\
\hline $\begin{array}{l}\text { Nonprotein energy (cal } / \mathrm{kg} / \\
\text { day) }\end{array}$ & Suckled & $136 \pm 10$ & $145 \pm 12$ \\
\hline Cysteine (mmol/kg/day) & Suckled & 0 & 0.8 \\
\hline
\end{tabular}

* Control group: suckled, intake unknown.

$\dagger$ Protein: Aminosyn (Abbott Laboratories), see Table 1 for composition.

¥ Fat: Liposyn (Abbott Laboratories), $10 \%$ safflower oil, $1.2 \%$ phospholipid, $2.5 \%$ glycerin; major fatty acids are linoleic $(77 \%)$, oleic $(13 \%)$, palmitic (7\%), and stearic acid $(2.5 \%)$. 
homogenate was frozen at $-20^{\circ} \mathrm{C}$ for DNA and protein analysis. The remainder of the homogenate was used for free amino acid and glutathione analyses following precipitation of the proteins in the homogenate with $15 \%$ trichloroacetic acid by centrifugation at $17,000 \times g$ for $20 \mathrm{~min}$. Amino acid and glutathione analyses were performed on the supernatant solution. Preparation of the liver for analysis was similar to that for the cerebrum.

DNA analyses of the tissues were performed by the method of Burton (2) and total protein analyses by the method of Lowry et al. (9). Amino acids were measured on a Beckman $119 \mathrm{CL}$ automatic amino acid analyzer (Beckman Instruments, Palo Alto, CA). Free and protein-bound cyst(e)ine concentrations were measured by the method of Gaitonde (5) as modified by Malloy et al. (10). Total glutathione concentrations were measured by the method of Tietze (21).

Significant differences between group means of the variables measured were determined by an unpaired two-tailed Student's $t$ test. A $P$ value of less than 0.05 was considered significant.

\section{RESULTS}

Twenty-four beagle pups were studied. The results from two control pups were excluded because of poor growth due to illness in their mother. The results from two US-TPN pups, and two STPN pups were excluded from data analysis because of centralline failures in these pups. The final data represent six control, six US-TPN, and six S-TPN pups.

There was a marked difference between the rate of weight gain for the suckled pups and the rate of weight gain for the experimental pups (Table 3 ). The suckled pups gained weight at a rate $(50 \mathrm{~g} /$ day $)$ that was significantly faster than the rate of gain in the US-TPN ( $33 \mathrm{~g} /$ day) or the S-TPN pups $(21 \mathrm{~g} /$ day). There were no differences in the rate of growth between the US-TPN and S-TPN groups.

The absolute weights of the livers of the pups that received TPN were less than the weights of the livers of the control pups. When weight was expressed as a percentage of body weight, however, there were no differences between the control and TPN pups (Table 4). Hepatic DNA concentrations were significantly reduced in the experimental pups (US-TPN $=1.5 \pm 0.6 \mathrm{mg} / \mathrm{g}$ liver and S-TPN $=1.4 \pm 0.7 \mathrm{mg} / \mathrm{g}$ liver) compared to the control pups $(2.4 \pm 0.5 \mathrm{mg} / \mathrm{g}$ liver $)$. There were no differences in hepatic DNA and protein measurements between the US-TPN and STPN groups.

The cerebral weights expressed as a percentage of body weight were not different between the three groups nor were cerebral DNA concentrations different (Table 4). Cerebral protein concentrations were decreased in the US-TPN $(74.2 \pm 16.2 \mathrm{mg} / \mathrm{g}$ cerebrum) and S-TPN groups $(69.6 \pm 3.6 \mathrm{mg} / \mathrm{g}$ cerebrum $)$ when compared with control values $(91.7 \mathrm{mg} / \mathrm{g}$ cerebrum), but there were no differences between the TPN groups.

Of the sulfur-containing amino acids in the plasma, total cyst(e)ine concentrations in the US-TPN pups $(4.9 \pm 1.8 \mu \mathrm{mols} /$ dl) were significantly less than in the S-TPN $(7.90 \pm 1.2 \mu \mathrm{mols} /$ $\mathrm{dl})$ or the control pups $(11.4 \pm 4.2 \mu \mathrm{mols} / \mathrm{dl})$ (Table 5). Plasma taurine concentrations were significantly less in both groups of TPN pups when compared with control pups, $P<0.05$. In the liver, cyst(e)ine concentrations were significantly increased in the

Table 3. Increase in body weight $(\bar{x} \pm S D)$

\begin{tabular}{lccc}
\hline & $\begin{array}{c}\text { Weight at } \\
\text { age 10 days } \\
(\mathrm{g})\end{array}$ & $\begin{array}{c}\text { Weight at } \\
\text { age 20 days } \\
(\mathrm{g})\end{array}$ & $\begin{array}{c}\text { Weight gain } \\
\text { per day } \\
(\mathrm{g})\end{array}$ \\
\hline Control & $465 \pm 127$ & $916 \pm 157$ & $50 \pm 9$ \\
TPN & $565 \pm 91$ & $829 \pm 118$ & $33 \pm 88^{*}$ \\
TPN + Cysteine & $468 \pm 75$ & $686 \pm 96 \dagger$ & $21 \pm 10^{*}$ \\
\hline
\end{tabular}

${ }^{*} \mathrm{P}<0.01$, experimental pups compared with controls.

$\dagger \mathrm{P}<0.05$, experimental pups compared with controls.
Table 4. Organ growth profiles $(\bar{x} \pm S D)$

\begin{tabular}{lccc}
\hline \multicolumn{1}{c}{ Organ } & Control & TPN & $\begin{array}{c}\text { TPN }+ \\
\text { cysteine }\end{array}$ \\
\hline Liver weight $(\%$ body weight) & $5.5 \pm 0.7$ & $4.8 \pm 0.4$ & $5.0 \pm 1.0$ \\
Liver DNA (mg/g) & $2.4 \pm 0.5$ & $1.5 \pm 0.6^{*}$ & $1.4 \pm 0.7^{*}$ \\
Liver protein $(\mathrm{mg} / \mathrm{g})$ & $155.2 \pm 27.5$ & $141.2 \pm 10.0$ & $128.3 \pm 14.4$ \\
Cerebral weight $(\%$ body & $2.3 \pm 0.5$ & $2.4 \pm 0.3$ & $2.7 \pm 0.4$ \\
$\quad$ weight) & & & \\
Cerebral DNA (mg/g) & $0.53 \pm 0.15$ & $0.67 \pm 0.10$ & $0.63 \pm 0.03$ \\
Cerebral protein $(\mathrm{mg} / \mathrm{g})$ & $91.7 \pm 12.7$ & $74.2 \pm 16.2^{*}$ & $69.6 \pm 3.6 \dagger$ \\
\hline
\end{tabular}

${ }^{*} P<0.05$, experimental pups compared with controls.

$\dagger P<0.01$, experimental pups compared with controls.

Table 5. Sulfur-containing amino acid concentrations $(\bar{x} \pm S D)$

\begin{tabular}{lccc}
\hline & Control & TPN & $\begin{array}{c}\text { TPN }+ \\
\text { cysteine }\end{array}$ \\
\hline Plasma $(\mu$ mol/dl) & & & \\
Methionine & $5.7 \pm 1.1$ & $4.4 \pm 3.6$ & $5.8 \pm 1.5$ \\
Cystathionine & $0.7 \pm 0.5$ & $1.1 \pm 0.6$ & $2.1 \pm 1.9$ \\
Cyst(e)ine & & & \\
$\quad$ Free & $7.7 \pm 2.7$ & $4.1 \pm 0.7$ & $5.7 \pm 0.6$ \\
$\quad$ Bound & $3.7 \pm 1.5$ & $1.0 \pm 0.7$ & $2.3 \pm 0.7$ \\
$\quad$ Sum & $11.4 \pm 4.2$ & $4.9 \pm 1.8^{*}$ & $7.9 \pm 1.2 \dagger$ \\
Taurine & $19.4 \pm 8.1$ & $6.9 \pm 4.0^{*}$ & $10.0 \pm 2.5^{*}$ \\
Liver $(\mu$ mol $/ 100 \mathrm{~g})$ & & & \\
Methionine & $28.8 \pm 5.1$ & $30.2 \pm 15.4$ & $26.3 \pm 7.6$ \\
Cystathionine & $4.6 \pm 3.0$ & $6.7 \pm 2.9$ & $6.5 \pm 1.0$ \\
Cyst(e)ine & $29.9 \pm 16.6$ & $46.9 \pm 13.7$ & $58.3 \pm 17.8^{*}$ \\
Taurine & $1744.9 \pm 737.1$ & $1457 \pm 270$ & $1610 \pm 386$ \\
Cerebrum $(\mu \mathrm{mol} / 100 \mathrm{~g})$ & & & \\
Methionine & $4.9 \pm 2.5$ & $9.4 \pm 3.3$ & $5.8 \pm 1.5$ \\
$\quad$ Cystathionine & $9.2 \pm 5.8$ & $56.8 \pm 18.4$ & $56.5 \pm 18.6 \neq$ \\
Cyst(e)ine & $11.9 \pm 2.1$ & $11.3 \pm 2.0$ & $11.5 \pm 1.9$ \\
$\quad$ Taurine & $1086 \pm 176$ & $961 \pm 86$ & $931 \pm 100$ \\
\hline
\end{tabular}

* $P<0.05$, experimental pups compared with controls.

$\dagger P<0.05$, TPN + cysteine compared with TPN.

$\ddagger P<0.005$, experimental pups compared wtih controls.

S-TPN pups $(58.3 \pm 17.8 \mu \mathrm{mols} / 100 \mathrm{~g})$ compared with the controls $(29.9 \pm 16.6 \mu \mathrm{mols} / 100 \mathrm{~g})$, but were not different from the US-TPN pups $(46.9 \pm 13.7 \mu$ mols $/ 100 \mathrm{~g})$. In the cerebrum, cystathionine concentrations were significantly increased in the US-TPN and S-TPN groups compared with controls, $P<0.005$.

Glutathione concentrations in the red blood cells and in the cerebrum of the US-TPN pups tended to be lower than in the controls or the S-TPN group (Table 6). In the liver, glutathione concentrations were significantly decreased in the US-TPN pups $(392 \pm 113 \mu \mathrm{mol} / 100 \mathrm{~g})$ compared with controls $(710 \pm 140$ $\mu \mathrm{mol} / 100 \mathrm{~g})$ and the S-TPN $(583 \pm 85 \mu \mathrm{mol} / 100 \mathrm{~g})$.

\section{DISCUSSION}

The discrepancy in the rate of weight gain between the.controls and the experimental pups could be caused by quantitative protein, fat, or total energy deficits in the two TPN groups. The rate of weight gain discrepancy could also be caused by qualitative differences in the nutritional intake between the groups, or it may be due to the effect that the route of the nutritional intake may have on growth. Infection in the pups that received TPN was not a problem. Protein/DNA ratios calculated from the averages of hepatic and cerebral protein and DNA concentrations would suggest the following: 1) the cells in the livers of the USTPN and S-TPN pups are larger but fewer in number than in the control pups (hepatic protein/DNA ratio-control $=64.6$, USTPN $=94.2$, and S-TPN $=91.5$ ); 2) the cells in the cerebrum 
Table 6. Glutathione concentrations $(\bar{x} \pm S D)$

\begin{tabular}{llll}
\hline & Control & TPN & $\begin{array}{l}\text { TPN }+ \\
\text { cysteine }\end{array}$ \\
\hline Red blood cell $(\mu \mathrm{mol} / 100 \mathrm{RBC})$ & $370 \pm 100$ & $339 \pm 36$ & $360 \pm 40$ \\
Liver $(\mu \mathrm{mol} / 100 \mathrm{~g})$ & $710 \pm 140$ & $392 \pm 113^{*}$ & $583 \pm 85 \dagger$ \\
Cerebrum $(\mu \mathrm{mol} / 100 \mathrm{~g})$ & $270 \pm 40$ & $225 \pm 39$ & $257 \pm 30$ \\
\hline
\end{tabular}

${ }^{*} P<0.005$, TPN compared with control.

$\dagger P<0.01$, TPN + cysteine compared with TPN.

are smaller in the US-TPN and S-TPN pups than in controls, but equal in number to the controls (cerebral protein/DNA ratio - control $=173$, US-TPN $=111, \mathrm{~S}-\mathrm{TPN}=110$ ). These data would be compatible with a sparing of brain cell proliferation during TPN and a reduced proliferation of cells in the liver due to a limited protein and energy intake (16). An obvious concern in using a suckled animal as a control is the inability to accurately document or control the nutritional intake. We, therefore, cannot determine a specific cause for the growth differences.

The principal question being tested, however, was whether or not the supplementation of TPN solutions with cysteine affected growth or biochemical measurements. This question was tested by determining differences between the two TPN groups. There were no differences in whole body weight or organ weight between the US-TPN and S-TPN groups. Similarly, there were no differences in the biochemical indices of growth (DNA and protein concentrations) in the liver and cerebrum between the two TPN groups. The addition of cysteine to TPN solutions used in growing pups, thus as might be expected, has no effect on growth when TPN is provided for a short period of time. Cysteine has been reported to be a nonessential amino acid during enteral nutrition in the growing beagle (1). Beagle pups do have significant activity of hepatic cystathionase (the rate-limiting enzyme for the synthesis of cysteine from cystathionine) (12). Our results, based on anthropometric and biochemical growth data would support the observation that cysteine is a nonessential amino acid in the growing pup under the conditions of this experiment. In addition, glutathione may serve as a reservior of cysteine (20) thus providing, for a short time, an additional source of cysteine for growth if endogenous synthesis or if an exogenous source was lacking.

The supplementation of TPN solutions with cysteine does have several effects on sulfur-containing compounds in the plasma and liver that may have important implications. As might be expected, cysteine-supplemented TPN produces a significantly higher plasma total cyst(e)ine concentration than in the unsupplemented pups, but it did not result in plasma cyst(e)ine concentrations greater than observed in the suckled pups.

Plasma taurine concentrations in the cysteine-supplemented and unsupplemented pups were less than those measured in the controls. Thus, even when an adequate substrate supply for the synthesis of taurine is provided, i.e. in the cysteine-supplemented TPN groups, the capacity for taurine synthesis to maintain plasma taurine concentrations comparable with those observed in suckled pups is limited. Thus, if maintaining plasma taurine concentrations is important, an exogenous supply of taurine is necessary even in an animal with significant cysteine-sulfinic acid decarboxylase activity (11). Cysteine-sulfinic acid decarboxylase has been suggested to be the limiting enzyme for the synthesis of taurine from cysteine (8).

Another interesting observation is the effect that TPN has on cerebral cystathionine concentrations. We have observed previously that cerebral cystathionine concentrations are significantly increased in beagle pups that receive TPN (12). The supplementation of TPN solutions with cysteine does not alter this finding. We suggest that the build-up of cystathionine in the cerebrum is because of the low activity of cystathionase in the cerebrum (18). This observation also illustrates the difference that the route of nutrition has on tissue metabolism. Because plasma methionine concentrations were not increased in the TPN pups, this implies a rapid uptake by tissues of methionine. Because methionine concentrations were not increased in the cerebrum, this implies a rapid transformation of methionine to cystathionine. In those organs with adequate cystathionase activity, e.g. the liver, cystathionine may be catabolized into cysteine. In the cerebrum, however, cystathionine accumulates due to limited cystathionase activity. During enteral nutrition this problem may be obviated by metabolism of excess methionine in the liver before the other major organs see the influx of exogenous methionine.

The major biochemical difference between the cysteine-supplemented and unsupplemented TPN groups was in the hepatic glutathione concentrations. Cysteine supplementation normalized hepatic glutathione concentrations. This observation suggests that, even in an animal that has a significant enzymatic capacity to synthesize cysteine from methionine (12), an exogenous source of cysteine may be necessary to support glutathione synthesis.

The relationship that antioxidant compounds such as glutathione may have on the modification of the toxic effects of oxygen has been appreciated $(4,7,14)$. That the synthesis of glutathione during TPN is significantly affected by the provision of an exogenous source of cysteine suggests that the supplementation of TPN solutions with cysteine might afford greater protection against the toxic effects of oxygen. A recent report has in fact demonstrated that the toxic effects of oxygen can be modified in rats by supplementing their enteral diets with cysteine (3). The major effect of supplementing the rat's diet with cysteine was reported to be an increase in lung glutathione concentrations (3). Thus, in infants exposed to high oxygen environments, there may be a role for the exogenous provision of cysteine during TPN in modifying the toxic effects of oxygen through the maintenance of glutathione synthesis.

\section{REFERENCES AND NOTES}

1. Burns RA, Milner JA 1981 Sulfur amino acid requirements of immature beagle dogs. J Nutr 111:2117

2. Burton K 1956 A study of the conditions and mechanism of the diphenylamine reaction for the colorimetric estimation of deoxyribonucleic acid. Biochem J $62: 315$

3. Deneke SM, Gershoff SN, Fanburg BL 1983 Potentiation of oxygen toxicity in rats by dietary protein or amino acid deficiency. J Appl Physiol 54:147

4. Frank L, Bucher JR, Roberts RJ 1969 Oxygen toxicity in neonatal and adult animals of various species. J Appl Physiol 45:699

5. Gaitonde MK 1967 A spectrophotometric method for the direct determination of cysteine in the presence of other naturally occurring amino acids. Biochem J 104:627

6. Gaull GE, Sturman JA, Raiha NCR 1972 Development of mammalian sulfur metabolism: absence of cystathionase in human fetal tissues. Pediatr Res 6:538

7. Haugaard N 1968 Cellular mechanisms of oxygen toxicity. Physiol Rev 48:311

8. Jacobsen JG, Smith LH 1968 Biochemistry and physiology of taurine and taurine derivatives. Physiol Rev 48:424

9. Lowry OH, Rosebrough NJ, Farr AL, Randall RJ 1951 Protein measurement with the Folin phenol reagent. J Biol Chem 193:265

10. Malloy MH, Rassin DK, Gaull GE 1981 A method for the measurement of free and bound plasma cyst(e)ine. Anal Biochem 113:407

11. Malloy MH, Rassin DK, Gaull GE, Heird WC 1981 Development of taurine metabolism in beagle pups: effects of taurine-free total parenteral nutrition. Biol Neonate 40:1

12. Malloy MH, Rassin DK, Heird WC, Gaull GE 1981 Transsulfuration in parenterally nourished beagle pups. Am J Clin Nutr 34:1520

13. Malloy MH, Rassin DK, Richardson CJ 1982 Cysteine supplementation at varying nitrogen intakes. Clin Res 30:887A

14. Meister A 1983 Selective modification of glutathione metabolism. Science 220:472

15. National Academy of Sciences 1974 Nutrient Requirements of Dogs, Number 8. Washington, DC, Natl Acad of Sci

16. Rozovski SJ, Winick $M 1979$ Nutrition and cellular growth. In: Winick M (ed) Human Nutrition. New York, Plenum Press, Vol I, pp 61-102

17. Snyderman SE 1971 The protein and amino acid requirements of the premature infant. In: Jonxis JHP Viser HKA, Traelstra JA (eds) Metabolic Processes in the Foetus and Newborn Infant. H. E. Stenfert Kroesse, Publ, Leiden, p 128

18. Sturman JA, Gaull GE, Niemann WH 1976 Cystathionine synthesis and degradation in brain, liver, and kidney of the developing monkey. J Neurochem 26:457

19. Tarver H, Schmidt CLA 1939 The conversion of methionine to cystine: 
experiments with radioactive sulfur. J Biol Chem 130:67

20. Tateishi N, Higashi T, Naruse A, Nakashima K, Shiozaki H, Sakamoto Y 1977 Rat liver glutáthione: possible role as a reservoir of cysteine. J Nutr 107:51

21. Tietze F 1969 Enzymatic method for quantitative determination of nanogram amounts of total and oxidized glutathione. Anal Biochem 27:502

22. Zlotkin SH, Anderson GH 1982 The development of cystathionase activity during the first year of life. Pediatr Res 16:65

23. Zlotkin SH, Bryan MH, Anderson GH 1981 Cysteine supplementation to cysteine-free intraveous feeding regimens in newborn infants. Am $\mathrm{J}$ Clin Nutr 34:914
24. Zlotkin SH, Anderson GH 1982. Sulfur balances in intravenously fed infants: effect of cysteine supplementation. Am J Clin Nutr 36:862

25. The authors wish to acknowledge the technical help of Tracy Prater and the secretarial assistance of Neva Hepler.

26. This research was supported by Abbott Laboratories Grant 81380 and Biomedical Research Support Grant DHHS 2S07-RR05427-21.

27. Presented in part at the Annual Meeting of the Society for Pediatric Research, Washington, D.C., May 3-6, 1983.

28. Reprint requests should be addressed to: Dr. Michael Malloy, Department of Pediatrics, University of Texas Medical Branch, Galveston, TX 77550

29. Received for publication December 1, 1983.

\title{
Food Protein-induced Enterocolitis: Altered Antibody Response to Ingested Antigen
}

\author{
PHILIP J. McDONALD, RANDALL M. GOLDBLUM, GREGGORY J. VAN SICKLE, AND \\ GERALDINE KEATING POWELL ${ }^{(32)}$ \\ Department of Pediatrics, Divisions of Gastroenterology and Immunology, University of Texas Medical Branch,
} Galveston, Texas USA

\section{Summary}

To evaluate the role of immunologic mechanisms in one specific syndrome of food intolerance in infants, food protein-induced enterocolitis, we measured class-specific serum antibodies to three food proteins, ovalbumin, soy, and cow milk, prior to diagnostic food challenges in 18 infants suspected to have this syndrome. Infants with positive challenge reactions to egg, soy, or cow milk had 5-10 times higher levels of IgA antibody directed against that food than did the infants with negative challenges. Levels of IgG antibody to soy and egg were also significantly higher (greater than $\mathbf{1 0}$-fold) in infants with positive challenge responses. There was no significant difference in levels of IgM food antibodies between the two groups. IgA anti-soy antibody levels rose in all 12 infants tested 2-10 weeks after a single soy feeding (challenge). However, IgM anti-soy antibody increased in the five infants who had a negative response to the challenge feeding and decreased in those seven with a positive response. The difference between the two groups was statistically significant $(P<0.01)$. Some correlation existed $(r=-0.68)$ between the increase in IgA anti-soy antibody and the decrease in IgM anti-soy antibody for infants with positive soy challenges. Although a pathogenic role for these antibodies is not proven, the findings suggest an altered immunologic response to ingestion of food antigens in infants with food protein-induced enterocolitis.

\section{Abbreviation}

\section{FPIE, food protein-induced enterocolitis}

Adverse reactions to cow milk or soy protein are common in infancy with an estimated incidence of 1 to $3 \%(5,11)$. Diverse gastrointestinal reactions have been described which include iron deficiency anemia associated with gastrointestinal blood loss (28), protein-losing enteropathy (26), malabsorption syndrome with defects in fat and/or carbohydrate absorption $(6,9,15)$, and a colitis-like syndrome $(12,17,20,22)$.
The pathogenic mechanisms in these reactions are undefined, but immunologic factors are frequently considered. Sensitization of $\mathrm{T}$ lymphocytes to cow milk antigens has been described in milk-sensitive infants (3). In addition, in some studies, increased serum antibodies to food proteins were thought to correlate with positive responses to oral cow milk challenge $(8,18,29)$. However, in other studies, no difference in serum antibodies was found between milk-sensitive and normal infants $(1,6,23)$. These contradictions may be related to variations in age and symptoms of the subjects, failure to confirm the diagnosis by a standardized oral challenge, or differences in the immunoassays utilized.

We attempted to define an immunological basis for one specific syndrome of infancy, FPIE, by correlating the levels of classspecific serum antibodies to three food proteins, ovalbumin, soy, and cow milk, with the response to a diagnostic oral challenge with the same three food proteins in infants suspected of having this syndrome. We also evaluated the change in anti-soy antibody titer in response to this oral challenge in a subgroup of these infants who received only a single soy feeding.

\section{MATERIALS AND METHODS}

Patient Selection. Approval for this study was obtained from the Human Research Committee at the University of Texas Medical Branch. Infants suspected of having FPIE were studied at the time of readmission for diagnostic food challenges. As described previously $(20)$, the infants presented initially with vomiting and chronic diarrhea which continued when they were switched from cow milk to soy-based formulas. Enterocolitis was diagnosed because the stools contained mucus, blood and leucocytes in addition to carbohydrate. The symptoms resolved completely within 2-3 days when whole protein was removed from the diet (oral electrolyte solution and subsequently a formula containing casein hydrolysate; Nutramigen, Mead Johnson) and no pathogens associated with colitis were isolated. The usual clinical management includes maintaining these infants on a casein hydrolysate formula (with no additional foods) for at 